\title{
PENGARUH GOAL SETTING DAN SELF-MONITORING DALAM PENGUASAAN KETERAMPILAN GERAK DAN MOTIVASI INTRINSIK SISWA SEKOLAH DASAR
}

\author{
Yusup Hidayat \\ FPOK Universitas Pendidikan Indonesia Bandung \\ (email: yusup_h2000@yahoo.com)
}

\begin{abstract}
Abstrak: Pengaruh Goal Setting dan Self-Monitoring dalam Penguasaan Keterampilan Gerak dan Motivasi Intrinsik Siswa Sekolah Dasar. Penelitian ini bertujuan untuk mengetahui pengaruh dari penetapan tujuan dan, pemantauan diri sebagai dua komponen penting dari self regulated learning (SRL) dengan penguasaan keterampilan motorik dan motivasi intrinsik dari siswa sekolah dasar. Penelitian ini dilakukan terhadap 70 mahasiswa (terdiri dari 35 siswa laki-laki dan 35 siswa perempuan), kelas empat dan lima berusia 10-12 tahun di SD Padasuka Bandung. Siswa dibagi menjadi 6 kelompok eksperimental dan satu kelompok kontrol dengan tugas acak. Data hasil perhitungan dengan menggunakan Manova dua faktorial menunjukkan bahwa penerapan tujuan dan, pemantauan diri memberikan pengaruh yang signifikan pada peningkatan keterampilan motorik anak panah melempar dan motivasi intrinsik. Tujuan dinamis meningkatkan keterampilan motorik melemparkan panah dan motivasi intrinsik lebih tinggi dari proses dan tujuan produk secara signifikan, sedangkan tujuan proses meningkatkan keterampilan motorik melempar panah dan motivasi intrinsik lebih tinggi dari tujuan produk secara signifikan. Secara umum, semua kelompok eksperimen menunjukkan peningkatan keterampilan motorik melemparkan panah dan motivasi intrinsik yang lebih tinggi dibandingkan dengan kelompok kontrol secara signifikan.
\end{abstract}

Kata Kunci: Pengaturan tujuan, pemantauan diri, keterampilan motorik, motivasi intrinsik

\begin{abstract}
The Influence Goal Setting and Self-Monitoring on the Mastery of Motor Skills and Intrinsic Motivation Elementary School Students. This study aims to determine the influences of goal setting and self-monitoring as two important components of self-regulated learning (SRL) to the mastery of motor skills and intrinsic motivation of the elementary school students. The Research conducted on 70 students (consisting of 35 male students and 35 female students), grade four and five with age of 10-12 year old at elementary school Padasuka Bandung. All students are divided into 6 experimental groups and one control group with random assignment. The computation result data using two-factorial MANOVA showed that goal setting and self-monitoring provides a significant influence on improving motor skills darts throwing and intrinsic motivation. The dynamic goal enhance throwing dart motor skills and intrinsic motivation is higher than process
\end{abstract}


and product goals significantly, while the process of throwing dart goal enhance motor skills and intrinsic motivation is higher than product goal significantly. In general, all experimental groups showed a significantly higher enhancement of throwing dart motor skills and intrinsic motivation compared with the control group.

Keywords: goal setting, self monitoring, motoric skill, intrinsic motivation

\section{PENDAHULUAN}

Self-Regulated Learning (SRL) adalah sebuah pendekatan pembelajaran yang digunakan sebagai strategi untuk membantu siswa agar menjadi lebih otonom dan termotivasi untuk menjadi seorang pembelajaran yang unggul (Elliot, Mc Gregor, \& Gable, 1999). Strategi SRL dipilih dan digunakan oleh siswa selama proses pembelajaran (Smith, 2001). Dua sub proses SRL yang memiliki peranan penting dalam proses belajar mengajar, termasuk dalam pembelajaran keterampilan gerak adalah penetapan tujuan dan pemantauan diri (Zimmerman \& Kitsantas, 1996, 1997). Keduanya merupakan komponen proses SRL yang sangat penting dalam selfdirected practice untuk mencapai otomatisasi keterampilan gerak. Sejumlah hasil penelitian menunjukkan bahwa penetapan tujuan dan pemantauan diri merupakan dua komponen pokok SRL yang memiliki pengaruh signifikan terhadap keberhasilan siswa dalam belajar, termasuk belajar keterampilan gerak (Zimmerman \& Kitsantas, 1999).

Penetapan tujuan terdiri atas penetapan tujuan proses, tujuan hasil, dan tujuan dinamik (Zimmerman dan Kitsantas, 1996, 1997; Schunk \& Ertmer, 1999; Filby, Maynard, \& Graydon, 1999; Cox, 2007). Penetapan tujuan proses (process goal) berkaitan dengan penggunaan teknik yang dapat membantu siswa untuk menguasai suatu tugas tertentu. Gould menyebutnya achievement goal strategy dan diyakini sebagai teknik yang efektif untuk mencapai tujuan akhir (Zimmerman \& Kitsantas, 1996). Pada tujuan proses, belajar keterampilan gerak dilakukan dengan membagi materi belajar atau keterampilan target ke dalam beberapa sub keterampilan sebagai perilaku target (Schmidt \& Wrisberg, 2000) atau critical features (Knudson \& Morrison, 1996).

Misalnya, keterampilan gerak servis dalam tenis dikompilasi dari perilaku target sikap tubuh, latihan melambungkan bola, mengayunkan raket, memukul bola, dan sikap akhir. Setiap perilaku target adalah sub tujuan yang harus dicapai oleh siswa secara bertahap. Oleh karena itu, tujuan proses memfokuskan perhatian siswa secara khusus pada aspek-aspek kunci dari pelaksanaan keterampilan gerak (Schmidt \& Wrisberg, 2000) dan usaha tahap demi tahap untuk memperbaiki keakurasian suatu keterampilan gerak.

Tujuan hasil merupakan jenis penetapan tujuan yang berorientasi pada hasil akhir, memfokuskan perhatian pada kesempurnaan tugas (Burton \& Weiss, 2008; Gould, 2001) atau pada 
pendemontrasian kompetensi yang tinggi agar mampu melebihi atau mengalahkan orang lain. Melalui penetapan tujuan hasil, siswa dituntut untuk membuktikan kompetensinya di antara siswa lain dengan mengerjakan tugas sebaik mungkin untuk memperoleh hasil tertinggi sehingga menjadi nomor satu (menjadi yang terbaik). Hal ini berarti kompetensi yang didemonstrasikan didasarkan pada standar ekternal berupa penampilan yang dilakukan individu lain, juga proses perbandingan sosial dengan individu yang lain (Sarrazin \& Famose, 1999; Moran, 2004; Cox, 2007, Burton \& Weiss, 2008).

Jadi, pencapaian tujuan tidak hanya tergantung pada upaya yang dilakukan, tetapi juga pada kemampuan dan kualitas permainan lawan. Contohnya antara lain, tujuan kemenangan dalam sebuah kejuaraan bolavoli, sepakbola, bulutangkis, dan lain-lain. Tujuan hasil biasanya disebut juga tujuan jangka panjang yang menekankan pada hasil akhir suatu kejuaraan dan pencapaian tujuannya ditunjang oleh tujuan performa dan tujuan proses yang ditetapkan sebelum dan selama latihan atau pertandingan.

Istilah tujuan dinamik (dynamic goal) atau shifting goal pertama kali dikembangkan oleh Zimmerman \& Kitsantas (1997, 1998, 1999) yang diartikan sebagai interfusi antara penetapan tujuan proses dengan tujuan hasil. Disebut shifting goal karena siswa melakukan sublimasi orientasi tujuan dari tujuan proses ke tujuan hasil. Sublimasi dilakukan ketika proses dasar telah dikuasai atau ketika otomatisasi gerak tercapai. Sublimasi orientasi tujuan di- dasarkan pada asumsi kebutuhan siswa untuk lebih fokus pada tujuan proses ketika siswa mulai belajar daripada tujuan hasil. Segera setelah teknik gerakan yang dibutuhkan dikuasai, siswa melakukan sublimasi ke tujuan hasil. Proses pembelajaran dimulai dengan menetapkan tujuan proses dengan cara mengelaborasi keterampilan target (misalnya, lob bertahan pada permainan bulutangkis) menjadi beberapa perilaku target, seperti posisi siap, gerakan ke arah satelkok, posisi memukul, ayunan raket ke belakang, ayunan raket ke depan, perkenaan raket dengan satelkok, gerak lanjut, dan kembali ke posisi semula.

Segera setelah setiap perilaku target dan kombinasinya dikuasai dengan benar dan dapat ditampilkan secara otomatis, siswa dapat melakukan sublimasi ke tujuan hasil dengan cara menentukan bidang target untuk arah pukulan yang dilakukannya. Penentuan bidang target ini dimaksudkan untuk mengetahui tingkat keberhasilan lob bertahan yang dilakukan. Jadi, tujuan dinamik adalah teknik menetapkan orientasi tujuan latihan siswa yang memfokuskan pada interfusi antara tujuan proses dengan tujuan hasil. Pada tahap awal latihan, siswa fokus pada proses penguasaan keterampilan gerak (tujuan proses) dan melakukan sublimasi pada tujuan hasil penampilan setelah proses dasar dikuasai (tujuan hasil).

Istilah pemantauan diri (self-monitoring, self-observation) pada awalnya berkembang di bidang psikologi dan dalam perkembangannya hingga kini, meluas ke bidang-bidanglain, termasuk pendidikan. Pemantauan diri adalah 
proses observasi yang dilakukan secara sistematis dan digunakan untuk mengakses kemajuan belajar guna dibandingkan dengan tujuan yang telah ditetapkan. Seperi dijelaskan Agran, Sinclair, Alper, Cavin, Wehmeyer, \& Hughes (2005:4) "Self-monitoring involves a student's self observation of a target behavior, followed by recording the occurrence". Pemantauan diri dapat menghasilkan perubahan perilaku karena individu dapat membedakan stimulus dan tanda-tanda perilaku yang akan ditampilkan. Pemantauan diri memungkinkan siswa membedakan perilaku target dan mengingatkannya atas kejadian sekarang dan yang akan datang yang terjadi di lingkungannya. Misalnya,jika saya menampilkan gerakan ini, maka ini yang akan terjadi. Dijelaskan lebih lanjut oleh Argan (1997) dan Hughes, Copeland, Agran, Wehmeyer, Rodi, \& Presley, (2002) bahwa pemantauan diri dapat bermanfaat sebagai sebuah strategi belajar yang terpusat pada diri sendiri. Pemantauan diri akan memberikan cara-cara yang efektif untuk memaksimalkan partisipasi siswa dan meningkatkan hasil belajar siswa. Pemantauan diri merupakan sub proses yang penting dalam self-regulated learning sebab menekankan siswa untuk fokus pada bahan yang sedang dipelajari dan mengakselerasi berfikir relatif (Zimmerman dan Paulson dalam Smith, 2001). Pemantauan diri dapat dilaksanakan dengan melakukan pengamatan dan perekaman perilakunya sendiri.

Dalam bidang pendidikan, pemantauan diri dapat dilakukan oleh siswa maupun guru. Tan (1997) mengemukakan bahwa seorang guru yang profesio- nal akan cenderung melakukan pemantauan diri terhadap semua yang dikerjaka. Demikian juga siswa yang pandai akan cenderung melakukan pemantauan diri terhadap kemajuan belajarnya. Ditambahkan Zimmerman (2002) bahwa pemantauan diri merupakan sebuah strategi yang dapat membantu siswa untuk meningkatkan prestasi belajar. Beberapa hasil penelitian yang dilakukan oleh Schunk (1985), Bandura (1986), Jacobson (1998), dan Ernsbarger (2002), menyimpulkan bahwa siswa yang menetapkan tujuan belajar dan melakukan pemantauan terhadap kemajuan belajarnya akan mencapai keberhasilan yang lebih tinggi. Demikian juga dalam belajar keterampilan gerak, sejumlah hasil penelitian membuktikan bahwa penetapan tujuan dan pemantauan diri dapat digunakan sebagai strategi membantu siswa untuk berprestasi. Singkatnya, pemantauan diri merupakan strategi yang penting dalam membentuk keberhasilan belajar siswa.

Sesuai dengan uraian di atas, diduga hasil belajar keterampilan gerak melempar anak panah dan motivasi intrinsik yang diberi perlakuan penetapan tujuan dinamik lebih tinggi dan signifikan dibandingkan dengan yang diberi perlakuan penetapan tujuan proses dan hasil baik secara keseluruhan pada subjek yang melakukan pemantauan diri maupun yang tidak melakukan pemantauan diri. Subjek yang melakukan pemantauan diri menunjukkan hasil belajar keterampilan gerak melempar anak panah dan motivasi intrinsik yang lebih tinggi dan signifikan daripada subjek yang tidak melakukan pemantauan diri. 


\section{METODE}

Sesuai dengan tujuan penelitian ini, yaitu untuk mengetahui hubungan kausal antara penetapan tujuan dan pemantauan diri dengan hasil belajar keterampilan gerak melempar anak panah dan motivasi intrinsik, metode penelitian yang digunakan adalah metode kuasi eksperimen (Shadish, Cook, \& Campbell, 2002). Metode eksperimen digunakan untuk menguji efektifitas pengaruh penetapan tujuan dan pemantauan diri terhadap hasil belajar keterampilan gerak melempar anak panah dan motivasi intrinsik, baik secara bersama-sama (multivariat) maupun secara independen (univariat).

Penelitian dilakukan di Sekolah Dasar Negeri Anyar Padasuka Bandung terhadap 70 orang siswa putra dan putri yang berusia 10-12 tahun (rata-rata = 11.1 tahun). Subjek penelitian dibagi ke dalam enam kelompok eksperimen dan satu kelompok kontrol dengan pemadanan secara random (matched random sampling). Desain penelitian yang digunakan adalah faktorial $3 \times 2$ (Kerlinger, 2002; Ary, Jacobs, \& Razavieh, 1990). Pelaksanaan penelitian dibagi ke dalam tiga tahapan, yakni tahap persiapan, pelaksanaan, dan akhir. Tahap persiapan berisi kegiatan penyeleksian subjek, tahap pelaksanaan adalah tahap pemberian perlakuan atau manipulasi, sedangkan tahap akhir berisi pelaksanaan kegiatan tes akhir.

Kondisi eksperimen didasarkan pada klasifikasi penetapan tujuan proses (A1), tujuan hasil (A2), dan tujuan dinamik (A3), serta klasifikasi menggunakan pemantauan diri (B1) dan tanpa pemantauan diri (B2). Dengan demi- kian, terdapat enam kelompok eksperimen, yaitu: (1) kelompok kombinasi antara tujuan proses dengan pemantauan diri disebut kelompok eksperimen satu (K-1/A1B1); (2) kelompok kombinasi antara tujuan proses dengan tanpa pemantauan diri disebut kelompok eksperimen dua (K-2/A1B2); (3) kelompok kombinasi antara tujuan hasil dengan pemantauan diri disebut kelompok eksperimen tiga (K-3/A2B1); (4) kelompok kombinasi antara tujuan hasil dengan tanpa pemantauan diri disebut kelompok eksperimen empat (K-4/A2B2); (5) kelompok kombinasi antara tujuan dinamik dengan pemantauan diri disebut kelompok eksperimen lima (K-5/A3B1); dan (6) kelompok kombinasi antara tujuan dinamikdengan tanpa pemantauan diri disebut kelompok eksperimen enam (K-6/A3B2), serta satu kelompok kontrol tanpa penetapan tujuan dan tanpa pemantauan diri (K-7).

Setiap kelompok ditempatkan di ruangan terpisah dan dites secara individual oleh seorang mahasiswa Program Studi Pendidikan Jasmani Kesehatan dan Rekreasi semester 9 (sembilan). Prosedur perlakuan mengacu kepada penelitian yang dilakukan oleh Zimmerman \& Kitsantas (1996), yakni 10 menit pertama sebelum perlakuan digunakan untuk demonstrasi keterampilan dan menjelaskan sistem penskoran. Setiap kelompok terlebih dahulu diberi penjelasan mengenai tata cara melempar anak panah, termasuk sub-sub keterampilan geraknya dan mendapatkan kesempatan untuk melatihnya tidak kurang dan 12 menit dan tidak lebih dari 20 menit 
Ada dua instrumen yang digunakan untuk menentukan efektivitas perlakuan, yaitu tes keterampilan melempar anak panah (dart throwing) dan skala motivasi intrinsik. Sasaran yang digunakan untuk melempar anak panah adalah sebuah papan yang terbuat dari kayu. Pada papan tersebut di buat 7 buah lingkaran dari yang terkecil dengan diameter $2.54 \mathrm{~cm}$ dan jarak antara lingkaran sejauh $2.54 \mathrm{~cm}$. Setiap zona sasaran memiliki nilai numerik, nilai 1 untuk zona sasaran besar, nilai 7 untuk zona sasaran terkecil, dan nilai 0 untuk zona sasaran di luar lingkaran. Sasaran diletakkan setinggi $1.77 \mathrm{~m}$ dan jarak pelempar ke sasaran sejauh 2.59 m. Setiap siswa diberi 6 anak panah untuk melakukan 6 kali lemparan, dan skor akhir dihitung rerata dari keenam lemparan. Rentang skor antara 0-7.

Skala motivasi intrinsik yang disusun mengacu kepada konstrak skala motivasi olahraga yang dikembangkan oleh Pelletier, Fortier, Vallerand, Tuson, \& Brie're (1999) dan Martens \& Webber
(2002). Konstrak motivasi intrinsik memiliki tiga dimensi konstrak, yaitu intrinsic motivation to know, intrinsic motivation to experience stimulation, dan intrinsic motivation to accomplish. Setiap dimensi terdiri atas 4 item dan keseluruhan berjumlah 12 item. Berdasarkan hasil analisis reliabilitas konsistensi internal diperoleh skor Alpha Cronbach untukintrinsic motivation to know $(0,697)$, intrinsic motivation to experience stimulation $(0,778)$, dan intrinsic motivation to accomplish $(0,789)$ dengan rerata sebesar 0,755 . Semua data yang dikumpulkan dianalisis dengan menggunakan Analisis Varian Multivariat Faktorial dua jalur (Manova) dan Anova satu jalur dengan bantuan Program SPSS. 16 (Field, 2009; Ghozali, 2009; Widarjono, 2010).

\section{HASIL}

Berdasarkan analisis menggunakan teknik Analisis Varian Multivariat (Manova) diperoleh besaran nilai rerata dan standar deviasi seperti dalam Tabel 1.

\section{Tabel 1. Deskripsi Statistik Rerata dan Deviasi Standar}

\begin{tabular}{|c|c|c|c|c|c|}
\hline \multirow{3}{*}{$\begin{array}{l}\text { Penetapan } \\
\text { Tujuan }\end{array}$} & \multirow{3}{*}{$\begin{array}{l}\text { Variabel } \\
\text { Dependen }\end{array}$} & \multicolumn{4}{|c|}{ Pemantauan Diri (A) } \\
\hline & & \multicolumn{2}{|c|}{$\begin{array}{l}\text { Dengan Pemantauan Diri } \\
\text { (B1) }\end{array}$} & \multicolumn{2}{|c|}{$\begin{array}{c}\text { Tanpa Pemantauan Diri } \\
\text { (B2) }\end{array}$} \\
\hline & & $M$ & $S D$ & $M$ & $S D$ \\
\hline Tujuan & Keterampilan & 21.00 & 3,651 & 17,70 & 4,001 \\
\hline Proses & Gerak & & & & \\
\hline (A1) & Motivasi Intrinsik & 28,60 & 3,921 & 25.80 & 3,795 \\
\hline Tujuan & Keterampilan & 15,50 & 3,951 & 15.10 & 3,985 \\
\hline Hasil & Gerak & & & & \\
\hline (A2) & Motivasi intrinsik & 23.50 & 3,951 & 21,60 & 3,921 \\
\hline Tujuan & Keterampilan & 28,60 & 2,119 & 23,40 & 4,248 \\
\hline Dinamik & Gerak & & & & \\
\hline (A3) & Motivasi Intrinsik & 40,20 & 2,150 & 31,80 & 4,237 \\
\hline
\end{tabular}


Uji Signifikansi Multivariat Main Effect

Tabel 2. Uji Multivariat (Multivariate test)

\begin{tabular}{lccccccc}
\hline & & \multicolumn{3}{c}{ Hypothesis } & Error & \multicolumn{2}{c}{ Partial Eta } \\
\multicolumn{1}{c}{ Effect } & & Value & F & df & df & Sig. & Squared \\
\hline Penetapan_Tujuan & Pillai's Trace & .734 & 15.669 & 4.000 & 108.000 & .000 & .367 \\
Pemantauan_Diri & Pillai's Trace & .320 & $12.495^{\text {a }}$ & 2.000 & 53.000 & .000 & .320 \\
$\begin{array}{l}\text { Penetapan_Tujuan } \\
\text { * Pemantauan_Diri }\end{array}$ & Pillai's Trace & .272 & 4.242 & 4.000 & 108.000 & .003 & .136 \\
\hline
\end{tabular}

Uji Signifikansi Univariat untuk Efek antar Subjek

Tabel 3. Tests of Between-Subjects Effects (Tes Efek antarsubjek)

\begin{tabular}{|c|c|c|c|c|c|c|c|}
\hline Source & $\begin{array}{c}\text { Dependent } \\
\text { Variable }\end{array}$ & $\begin{array}{l}\text { Type III Sum of } \\
\text { Squares }\end{array}$ & $\mathrm{df}$ & $\begin{array}{l}\text { Mean } \\
\text { Square }\end{array}$ & $\mathrm{F}$ & Sig. & $\begin{array}{c}\text { Partial } \\
\text { Eta } \\
\text { Squared }\end{array}$ \\
\hline \multirow[t]{2}{*}{ Penetapan_Tujuan } & $\mathrm{Y} 1$ & 1167.433 & 2 & 583.717 & 42.011 & .000 & .609 \\
\hline & $\mathrm{Y} 2$ & 1866.433 & 2 & 933.217 & 67.183 & .000 & .713 \\
\hline \multirow[t]{2}{*}{ Pemantauan_Diri } & Y1 & 132.017 & 1 & 132.017 & 9.501 & .003 & .150 \\
\hline & $\mathrm{Y} 2$ & 286.017 & 1 & 286.017 & 20.590 & .000 & .276 \\
\hline \multirow{2}{*}{$\begin{array}{l}\text { Penetapan_Tujuan } \\
* \\
\text { Pemantauan_Diri }\end{array}$} & Y1 & 58.433 & 2 & 29.217 & 2.103 & .132 & .072 \\
\hline & $\mathrm{Y} 2$ & 124.033 & 2 & 62.017 & 4.465 & .016 & .142 \\
\hline \multirow[t]{2}{*}{ Error } & Y1 & 750.300 & 54 & 13.894 & & & \\
\hline & $\mathrm{Y} 2$ & 750.100 & 54 & 13.891 & & & \\
\hline
\end{tabular}

a. $\mathrm{R}$ Squared $=.644$ (Adjusted R Squared $=.611$ )

b. $\mathrm{R}$ Squared $=.752$ (Adjusted R Squared $=.729)$

\section{Uji Pasangan}

\section{Uji Pasangan antar A}

Berdasarkan hasil uji perbandingan pasangan antar A, diperoleh hasil sebagai berikut. (1) Penetapan tujuan proses (rerata $=19,350)$ memberikan pengaruh lebih tinggi dan signifikan daripada penetapan tujuan hasil (rerata $=15,300$ ) terhadap keterampilan gerak melempar anak panah dengan nilai $\mathrm{p}=0,001<$ 0,05. (2) Penetapan tujuan dinamik (rerata $=26,000$ ) memberikan pengaruh lebih tinggi dan signifikan daripada penetapan tujuan proses (rerata $=19,350$ ) terhadap keterampilan gerak melempar anak panah dengan nilai $\mathrm{p}=0,000<$ 0,05 . (3) Penetapan tujuan dinamik (rerata $=26,000$ ) memberikan pengaruh lebih tinggi dan signifikan daripada penetapan tujuan hasil (rerata $=15,300$ ) terhadap keterampilan gerak melempar anak panah dengan nilai $\mathrm{p}=0,000<$ 0,05 . (4) Penetapan tujuan proses (rerata $=27,200)$ memberikan pengaruh lebih tinggi dan signifikan daripada penetapan tujuan hasil (rerata $=22,550$ ) terhadap motivasi intrinsik dengan nilai $\mathrm{p}=$ $0,000<0,05$. (5) Penetapan tujuan dina- 
mik (rerata $=36,000)$ memberikan pengaruh lebih tinggi dan signifikan daripada penetapan tujuan proses (rerata = $27,200)$ terhadap motivasi intrinsik dengan nilai $\mathrm{p}=0,000<0,05$. (6) Penetapan tujuan dinamik (rerata $=36,000$ ) memberikan pengaruh lebih tinggi dan signifikan daripada penetapan tujuan hasil (rerata $=22,550)$ terhadap motivasi intrinsik dengan nilai $\mathrm{p}=0,000<0,05$.

\section{Uji Pasangan antar B}

Berdasarkan hasil uji perbandingan pasangan antar B, diperoleh hasil sebagai berikut. (1) Keterampilan gerak melempar anak panah siswa yang melakukan pemantauan diri (rerata = $21,700)$ lebih tinggi dan signifikan daripada siswa yang tidak melakukan pemantauan diri (rerata $=18,733$ ) dengan nilai $p=0,003<0,05$. (2) Motivasi intrinsik siswa yang melakukan pemantauan diri (rerata $=30,767$ ) lebih tinggi dan signifikan daripada siswa yang tidak melakukan pemantauan diri (rerata $=$ 26,400 ) dengan nilai $\mathrm{p}=0,000<0,05$.

\section{Uji Pasangan Interaksi}

Berdasarkan hasil uji perbandingan pasangan interaksi diperoleh hasil sebagai berikut. (1) Siswa yang diberi perlakuan tujuan proses, keterampilan gerak melempar anak panah siswa yang melakukan pemantauan diri (rerata = 21.000) lebih tinggi dan signifikan dari siswa yang tidak melakukan pemantauan diri (rerata $=17,700)($ A1B1-A1B2). (2) Siswa yang diberi perlakuan tujuan hasil, keterampilan gerak melempar anak panah siswa yang melakukan pemantauan diri (rerata $=15,500$ ) tidak berbeda secara signifikan dengan siswa yang tidak melakukan pemantauan diri (rerata $=15,100)($ A2B1-A2B2). (3) Siswa yang diberi perlakuan tujuan dinamik, keterampilan gerak melempar anak panah siswa yang melakukan pemantauan diri (rerata $=28,600$ ) lebih tinggi dan signifikan dari siswa yang tidak melakukan pemantauan diri (rerata $=23,400$ ) (A3B1-A3B2). (4) Siswa yang diberi perlakuan tujuan proses, motivasi intrinsik siswa yang melakukan pemantauan diri (rerata $=28,600$ ) lebih tinggi dan signifikan dari siswa yang tidak melakukan pemantauan diri (rerata $=25,800$ ) (A1B1-A1B2). (5) Siswa yang diberi perlakuan tujuan hasil, motivasi intrinsik siswa yang melakukan pemantauan diri (rerata $=25,500$ ) tidak berbeda secara signifikan dari siswa yang tidak melakukan pemantauan diri (rerata $=21,600$ ) (A2B1-A2B2). (6) Siswa yang diberi perlakuan tujuan dinamik, motivasi intrinsik siswa yang melakukan pemantauan diri (rerata $=40,200$ ) lebih tinggi dan signifikan dari siswa yang tidak melakukan pemantauan diri (rerata $=31,200$ ) (A3B1-A3B2). (7) Siswa yang melakukan pemantauan diri, keterampilan gerak melempar anak panah siswa yang diberi perlakuan tujuan proses (rerata = 21.000) lebih tinggi dan signifikan dari siswa yang diberi perlakuan tujuan hasil (rerata =15,500) (A1B1-A2B1). (8) Siswa yang melakukan pemantauan diri, keterampilan gerak melempar anak panah siswa yang diberi perlakuan tujuan dinamik (rerata $=28,600$ ) lebih tinggi dan signifikan dari siswa yang diberi perlakuan tujuan proses (rerata = 21.000) (A1B1-A3B1). (9) Siswa yang melakukan pemantauan diri, keterampilan gerak melempar anak panah sis- 
wa yang diberi perlakuan tujuan dinamik (rerata $=28,600$ ) lebih tinggi dan signifikan dari siswa yang diberi perlakuan tujuan hasil (rerata $=15,500$ ) (A2B1-A3B1). (10) Siswa yang tidak melakukan pemantauan diri, keterampilan gerak melempar anak panah siswa yang diberi perlakuan tujuan proses (rerata $=17,700$ ) lebih tinggi dan signifikan dari siswa yang diberi perlakuan tujuan hasil (rerata $=15,100)$ (A1B2A2B2). (11) Siswa yang tidak melakukan pemantauan diri, keterampilan gerak melempar anak panah siswa yang diberi perlakuan tujuan dinamik (rerata $=23,400$ ) lebih tinggi dan signifikan dari siswa yang diberi perlakuan tujuan proses $($ rerata $=17,700)($ A1B2-A3B2). (12) Siswa yang tidak melakukan pemantauan diri, keterampilan gerak melempar anak panah siswa yang diberi perlakuan tujuan dinamik (rerata $=23,400$ ) lebih tinggi dan signifikan dari siswa yang diberi perlakuan tujuan hasil (rerata $=15,100)($ A2B2-A3B2). (13) Siswa yang melakukan pemantauan diri, motivasi intrinsik siswa yang diberi perlakuan tujuan proses (rerata $=28,600$ ) lebih tinggi dan signifikan dari siswa yang diberi perlakuan tujuan hasil (rerata $=23,500)$ (A1B2-A2B2). (14) Siswa yang melakukan pemantauan diri, motivasi intrinsik siswa yang diberi perlakuan tujuan dinamik (rerata $=40,200$ ) lebih tinggi dan signifikan dari siswa yang diberi perlakuan tujuan proses (rerata $=28,600)($ A1B2-A3B2). (15) Siswa yang melakukan pemantauan diri, keterampilan gerak melempar anak panah siswa yang diberi perlakuan tujuan dinamik (rerata $=40,200$ ). lebih tinggi dan signifikan dari siswa yang diberi perlakuan tujuan hasil (rerata $=23,500$ ) (A2B2-A3B2). (16) Siswa yang tidak melakukan pemantauan diri, keterampilan gerakmelempar anak panah siswa yang diberi perlakuan tujuan proses (rerata $=$ $25,800)$ lebih tinggi dan signifikan dari siswa yang diberi perlakuan tujuan hasil $($ rerata $=21,600)($ A1B2-A2B2). (17) Siswa yang tidak melakukan pemantauan diri, motivasi intrinsik siswa yang diberi perlakuan tujuan dinamik (rerata $=31,800$ ) lebih tinggi dan signifikan dari siswa yang diberi perlakuan tujuan proses (rerata $=25,800$ ) (A1B2A3B2). (18) Siswa yang tidak melakukan pemantauan diri, motivasi intrinsik siswa yang diberi perlakuan tujuan dinamik (rerata $=31,800$ ) lebih tinggi dan signifikan dari siswa yang diberi perlakuan tujuan hasil (rerata $=21,600$ ) (A2B2-A3B2).

\section{Perbandingan Kelompok Kontrol de- ngan Kelompok Eksperimen}

Perbandingan hasil kelompok kontrol dengan kelompok eksperimen melalui analisis jalur dapat dilihat pada Tabel 4.

\section{PEMBAHASAN}

Berdasarkan hasil pengujian Analisis Varian Multivariat (Manova) terhadap perbedaan hasil belajar antara penetapan tujuan proses, tujuan hasil, dan tujuan dinamik diperoleh hasil yang mendukung hipotesis. Terbukti kelompok subjek yang pembelajarannya berorientasi pada penetapan tujuan dinamik menunjukkan hasil belajar keterampilan gerak melempar anak panah 
Tabel 4. Rangkuman Hasil Analisis Varian Satu Jalur

Keterampilan Gerak Melempar Anak Panah

\begin{tabular}{lccccc}
\hline & Sum of Squares & df & Mean Square & F & Sig. \\
\hline Between Groups & 1881.600 & 6 & 313.600 & 25.569 & .000 \\
Within Groups & 772.700 & 63 & 12.265 & & \\
Total & 2654.300 & 69 & & & \\
\hline
\end{tabular}

Motivasi Intrinsik

\begin{tabular}{lccccc}
\hline & Sum of Squares & df & Mean Square & F & Sig. \\
\hline Between Groups & 2952.886 & 6 & 492.148 & 33.694 & .000 \\
Within Groups & 920.200 & 63 & 14.606 & & \\
Total & 3873.086 & 69 & & & \\
\hline
\end{tabular}

Tabel 5. Perbandingan Kelompok Kontrol dengan Kelompok Eksperimen untuk Varaibel Keterampilan Gerak Melempar Anak Panah

\begin{tabular}{|c|c|c|c|c|}
\hline No. & $\begin{array}{c}\text { Kelompok yang } \\
\text { dibandingkan }\end{array}$ & P_Value & $\alpha$ & Keterangan \\
\hline \multicolumn{5}{|c|}{ Variabel Keterampilan Gerak Melempar Anak Panah } \\
\hline 1 & Kontrol dengan $\mathrm{A}_{1} \mathrm{~B}_{1}$ & 0,000 & 0,05 & Signifikan \\
\hline 2 & Kontrol dengan $\mathrm{A}_{1} \mathrm{~B}_{2}$ & 0,001 & 0,05 & Signifikan \\
\hline 3 & Kontrol dengan $\mathrm{A}_{2} \mathrm{~B}_{1}$ & 0,052 & 0,05 & Tidak Signifikan \\
\hline 4 & Kontrol dengan $\mathrm{A}_{2} \mathrm{~B}_{2}$ & 0,090 & 0,05 & Tidak Signifikan \\
\hline 5 & Kontrol dengan $\mathrm{A}_{2} \mathrm{~B}_{1}$ & 0,000 & 0,05 & Signifikan \\
\hline 6 & Kontrol dengan $\mathrm{A}_{3} \mathrm{~B}_{2}$ & 0,000 & 0,05 & Signifikan \\
\hline \multicolumn{5}{|c|}{ Variabel Motivasi Intrinsik } \\
\hline 1 & Kontrol dengan $\mathrm{A}_{1} \mathrm{~B}_{1}$ & 0,000 & 0,05 & Signifikan \\
\hline 2 & Kontrol dengan $\mathrm{A}_{1} \mathrm{~B}_{2}$ & 0,001 & 0,05 & Signifikan \\
\hline 3 & Kontrol dengan $\mathrm{A}_{2} \mathrm{~B}_{1}$ & 0,030 & 0,05 & Signifikan \\
\hline 4 & Kontrol dengan $\mathrm{A}_{2} \mathrm{~B}_{2}$ & 0,271 & 0,05 & Tidak Signifikan \\
\hline 5 & Kontrol dengan $\mathrm{A}_{2} \mathrm{~B}_{1}$ & 0,000 & 0,05 & Signifikan \\
\hline 6 & Kontrol dengan $A_{3} B_{2}$ & 0,000 & 0,05 & Signifikan \\
\hline
\end{tabular}

Keterangan:

$\mathrm{A}_{1} \mathrm{~B}_{1} \quad=$ Kelompok Eksperimen 1;

$\mathrm{A}_{1} \mathrm{~B}_{2} \quad=$ Kelompok Eksperimen 2;

$\mathrm{A}_{2} \mathrm{~B}_{1} \quad=$ Kelompok Eksperimen 3;

$\mathrm{A}_{2} \mathrm{~B}_{2} \quad=$ Kelompok Eksperimen 4;

$\mathrm{A}_{2} \mathrm{~B}_{2}=$ Kelompok Eksperimen 5;

$\mathrm{A}_{3} \mathrm{~B}_{2} \quad=$ Kelompok Eksperimen 6;

yang lebih tinggi secara signifikan daripada penetapan tujuan proses dan tujuan hasil. Penemuan ini mendukung hasil penelitian sebelumnya yang telah dilakukan oleh Zimmerman dan Kitsan- tas $(1997,1999)$. Dilaporkan dalam hasil penelitiannya bahwa kelompok eksperimen tujuan dinamik menunjukkan hasil belajar yang lebih tinggi dan signifikan daripada penetapan tujuan pro- 
ses dan hasil, sementara kelompok eksperimen tujuan proses menunjukkan hasil belajar yang lebih tinggi dan signifikan daripada tujuan hasil.

Zimmerman dan Kitsantas berhasil membuktikan hipotesis yang menyatakan bahwa hasil belajar keterampilan gerak yang terbaik dapat dicapai ketika siswa melakukan sublimasi penetapan tujuan dan pemantauan diri dari penetapan tujuan proses ke tujuan hasil setelah otomatisasi gerakan tercapai. Dilaporkan dalam penelitiannya bahwa kelompok eksperimen tujuan dinamik tidak hanya berhasil mencapai skor tertinggi dalam penguasaan keterampilan gerak melempar anak panah, tetapi juga memiliki tingkat motivasi intrinsik (efikasi diri, reaksi diri, dan minat intrinsik) paling tinggi. Bahkan dalam penelitian berikutnya, Zimmerman dan Kitsantas (1999) menemukan hasil yang sama, meskipun jenis keterampilannya berbeda.

Penetapan tujuan dinamik adalah kombinasi antara penetapan tujuan proses dan tujuan hasil. Siswa memfokuskan pembelajarannya pada proses penguasaan setiap bagian gerakan dan sekaligus pada pencapaian hasil akhir. Tujuan dinamik bersifat hirarkis, pada tahap awal belajar siswa fokus pada proses penguasaan setiap aspek kunci dari keterampilan gerak yang dipelajarinya dan melakukan sublimasi tujuan pada hasil performa setelah proses dasar dikuasai. Adanya sublimasi tujuan, selain menunjukkan bahwa tujuan dinamik bersifat hirarkis, juga menginformasikan kepada siswa tentang pentingnya ultimate outcome dari keterampilan gerak yang dikuasainya. Dengan kata lain, siswa mengetahui dan memahami tentang pentingnya hasil akhir dari proses belajar yang dilakukan dan akhirnya dapat mengurangi tuntutan metakognisi dari keterampilan yang harus ditampilkan.

Pengetahuan atau pemahaman siswa tentang hasil belajar yang dicapai (knowledge of result) merupakan faktor penting yang besar pengaruhnya terhadap pencapaian tujuan sebab dapat mengendalikan belajar dan penampilan (Silvestri, 2001) melalui pemberian informasi umpan balik baik secara verbal maupun non verbal berkenaan dengan hasil dari belajar suatu keterampilan gerak dikaitkan dengan tujuan yang ingin dicapai. Magill (2003) menyebutkan tiga fungsi penting dari pengetahuan tentang hasil, yaitu memberikan informasi spesifik mengenai kesalahan siswa ketika melakukan keterampilan gerak, memberikan penguatan, dan meningkatkan motivasi siswa.

Hal-hal inilah yang menyebabkan penetapan tujuan dinamik dapat memberikan pengaruh yang lebih tinggi secara signifikan daripada penetapan tujuan proses yang hanya fokus pada aspek-aspek kunci dari keterampilan gerak yang dipelajari. Beberapa hasil penelitian Zimmerman dan Kitsantas (1997, 1999) menemukan bahwa penetapan tujuan dinamik tidak hanya memberikan pengaruh lebih tinggi terhadap hasil belajar keterampilan gerak tetapi juga menumbuhkan efek motivasional (efikasi diri, reaksi diri, dan minat intrinsik) yang lebih tinggi daripada jenis penetapan tujuan yang lain.

Terbuktinya penetapan tujuan dinamik memberikan pengaruh lebih tinggi 
secara signifikan dari penetapan tujuan proses memberi informasi tentang adanya perspektif multi tujuan atau multiple goal strategy dalam penguasaan keterampilan gerak. Hal ini memberikan implikasi penting terhadap penetapkan tujuan yang bersifat hirarkis dalam kaitanya dengan proses pembelajaran. Artinya, untuk menguasai suatu keterampilan gerak secara lebih efektif dan efisien siswa dapat menetapkan tujuan belajar yang ingin dicapai secara hirarkis sesuai dengan yang dikehendaki (Steinberg \& Maurer, 1999; Filby, et al, 1999). Dengan menetapkan tujuan secara hirarkis diharapkan siswa dapat lebih bebas dan lebih termotivasi untuk verlatih. Implikasi lebih lanjut, siswa dapat mengelaborasi tujuan belajar yang ingin dicapai menjadi sub-subtujuan yang lebih spesifik dan realistik. Elaborasi ini penting sebab pencapaian suatu tujuan memiliki efek kumulatif dalam pencapaian tujuan-tujuan verikutnya.

Implikasi lain dari strategi multi tujuan ini adalah hasil belajar keterampilan gerak akan lebih efektif jika proses pembelajarannya berorientasi pada lebih dari satu jenis penetapan tujuan. Sejumlah penelitian telah dilakukan untuk mengetahui pengaruh stretegi multi tujuan ini, salah satu di antaranya dilakukan oleh Filby, et al. (1999) yang melakukan penelitian tentang pengaruh 4 jenis penetapan tujuan terhadap hasil belajar keterampilan menendang bola ke dinding (sepakbola) dengan menggunakan tes Wall Volley.

Subjek dibagi ke dalam 5 kelompok yakni kelompok (1) penetapan tujuan hasil; (2) penetapan tujuan proses; (3) penetapan tujuan dinamik; (4) penetapan tujuan hasil, performa, dan proses; (5) kelompok tanpa tujuan (kontrol). Hasilnya terbukti kelompok eksperimen 4 memiliki hasil belajar lebih tinggi dibandingkan ketiga kelompok eksperimen yang lain dan hasil terendah dicapai oleh kelompok eksperimen penetapan tujuan hasil. Penetapan tujuan hasil kurang efektif ketika dipergunakan secara soliter terpisah dari yang lain, tetapi menjadi sangat efektif ketika dikombinasikan dengan penetapan tujuan performa dan tujuan proses. Dijelaskan oleh Cox (2007) bahwa penggunaan kombinasi penetapan tujuan merupakan cara yang terbaik untuk mengembangkan aspek-aspek psikologis dan juga meningkatkan penampilan. Hal terpenting untuk para guru dan siswa, mereka harus memahami secara jelas perbedaan setiap jenis penetapan tujuan sehingga dapat menggunakannya secara efektif.

Adanya perbedaan hasil belajar antara tujuan proses dan hasil antara lain disebabkan karena penetapan tujuan proses lebih menfokuskan perhatian siswa secara khusus pada aspek-aspek kunci dari pelaksanaan keterampilan gerak dan usaha tahap demi tahap untuk memperbaiki keakurasian suatu keterampilan gerak. Pada pembelajaran yang berorientasi pada penetapan tujuan proses, belajar dipandang sebagai tujuan pembelajaran dan ukuran kesuksesan belajar ditekankan pada penguasaan keterampilan. Penetapan tujuan proses mendorong siswa untuk memahami sesuatu secara lebih mendalam dengan menerapkan berbagai usaha belajar. 
Untuk itu, kegagalan atau kesalahan dipandang sebagai bagian dari proses belajar dan dijadikan sebagai tantangan sekaligus kesempatan untuk belajar menguasai keterampilan yang baru, mengembangkan keterampilan yang sudah dimiliki secara lebih baik. Berbeda dengan penetapan tujuan hasil, belajar tidak dipandang sebagai tujuan pembelajaran, tetapi lebih berorientasi pada pencapaian hasil sebaik mungkin tanpa ditampilkannya. Hal ini bisa menyebabkan siswa kurang menghargai keterlibatan belajar dan kurang usaha untuk belajar (Sarrazin \& Famose, 1999), menghindari tantangan, dan menuntun siswa pada perasaan cemas tentang keberhasilan dan kegagalan.

Terbuktinya hipotesis yang menyatakan bahwa hasil belajar keterampilan gerak melempar anak panah dan motivasi intrinsik siswa yang melakukan pemantauan diri yang diberi penetapan tujuan dinamik lebih tinggi dibandingkan dengan yang diberi penetapan tujuan proses dan tujuan hasil pada kelompok siswa yang menggunakan pemantauan diri mendukung hasil penelitian sebelumnya yang dilakukan oleh Zimmerman \& Kitsantas (1997, 1999). Ketika penetapan tujuan dikonstruksi dan ditetapkan, kemampuan untuk melakukan kontrol atau memonitor diri menjadi sangat penting sebab memfokuskan perhatian siswa terhadap isyarat-isyarat internal dan eksternal, meningkatkan kesadaran diri, dan dapat melakukan kontrol lebih baik terhadap strategi intervensi yang digunakan. Melalui pemantauan diri siswa dapat merekam kemajuan belajarnya yang berguna untuk bahan penilaian diri. De- ngan demikian, pemantauan diri sangat penting dalam proses self-regulated practice untuk mencapai otomatisasi keterampilan gerak dan peningkatan motivasi diri serta menjadi dasar strategi dalam Self-Regulated Learning. Selain itu, melalui pemantauan diri siswa dapat memperoleh informasi mengenai hasil usaha belajar yang disebut Knowledge of Result. Pengetahuan atau pemahaman siswa tentang hasil usaha belajar yang dicapai merupakan faktor penting yang besar pengaruhnya terhadap peningkatan motivasi belajar selanjutnya.

Seperti diketahui, salah satu komponen yang sangat penting dalam menentukan keberhasilan belajar adalah motivasi. Motivasi merupakan energi psikologis yang dapat membangkitkan semangat atau kegairahan siswa dalam belajar, mempertahankan kegairahan tersebut dan mengarahkan semua aktivitas belajar kepada pencapaian tujuan. Knowledge of Result dapat juga memberikan informasi umpan balik baik secara verbal maupun nonverbal berkenaan dengan hasil belajar suatu keterampilan gerak dikaitkan dengan tujuan yang ingin dicapai. Siswa dapat mengetahui informasi spesifik mengenai kesalahan yang dilakukan sehingga dapat melakukan upaya perbaikan sesuai dengan kesalahan yang dilakukan.

Terbuktinya hipotesis yang menyatakan hasil belajar keterampilan melempar anak panah dan motivasi intrinsik yang menggunakan pemantauan diri lebih tinggi dan signifikan dari hasil belajar yang tidak menggunakan pemantauan diri mendukung penelitian-penelitian sebelumnya. Misalnya, penelitian yang dilakukan oleh Zimerman dan 
Kitsantas (1997, 1999). Hasil penelitian ini memberi informasi bahwa dengan pemantauan diri siswa dapat merekam kemajuan dalam mencapai tujuan yang dikehendaki, memungkinkan siswa untuk memperoleh data mengenai kemajuan belajar yang dicapai, dan hal ini sangat berguna untuk bahan penilain diri dan meningkatkan motivasi belajar siswa.

Pada akhirnya dapat membantu siswa untuk mencapai hasil belajar yang lebih baik. Sebaliknya, dengan siswa yang tidak menggunakan pemantauan diri, siswa tidak memperoleh umpan balik atas usaha belajar, tidak mengetahui kesalahan yang dilakukan selama proses belajar sehingga tidak dapat mengontrol hasil belajar. Kondisi ini kurang kondusif untuk meningkatkan motivasi belajar siswa sehingga memungkinkan hasil belajarnya kurang memuaskan atau rendah.

Demikian juga dengan hasil penghitungan perbandingan antara semua kelompok eksperimen dengan kelompok kontrol, terbukti untuk hasil belajar keterampilan gerak melempar anak panah hanya kelompok $\mathrm{A}_{2} \mathrm{~B}_{1}$ (kelompok penetapan tujuan hasil dan pemantauan diri) dan $\mathrm{A}_{2} \mathrm{~B}_{2}$ (kelompok penetapan tujuan hasil dan tanpa pemantauan diri) hasilnya tidak ada perbedaan signifikan, sementara untuk motivasi intrinsik hanya dengan kelompok $\mathrm{A}_{2} \mathrm{~B}_{2}$ (kelompok penetapan tujuan hasil dan tanpa pemantauan diri) hasilnya menunjukkan tidak ada perbedaan signifikan. Perbandingan kelompok penetapan tujuan dinamik baik yang dilengkapi dengan pemantauan diri maupun tidak dilengkapi dengan pemantauan diri ha- silnya menunjukkan paling tinggi. Artinya, penetapan tujuan dinamik merupakan alternatif terbaik yang bisa dijadikan pertimbangan oleh guru pendidikan jasmani untuk digunakan ketika menyusun tujuan pembelajaran pendidikan jasmani.

Adapun tidak adanya perbedaan yang signifikan antara kelompok kontrol $\mathrm{A}_{2} \mathrm{~B}_{1}$ dan $\mathrm{A}_{2} \mathrm{~B}_{2}$ pada variabel keterampilan gerak melempar anak panah dan kelompok $\mathrm{A}_{2} \mathrm{~B}_{2}$ pada variabel motivasi intrinsik (mungkin) disebabkan antara lain karena tujuan lebih bersifat trait. Artinya, setiap orang secara spontan akan menetapkan tujuan atas setiap tindakan yang dilakukannya. Siswa kelompok kontrol menetapkan tujuan hasil terutama karena dorongan untuk mencapai hasil yang terbaik atau kebutuhan untuk berprestasi cukup tinggi. Seperti dipahami, kebutuhan untuk berprestasi merupakan salah satu faktor penting yang mem-pengaruhi pencapaian tujuan (Magill, 2003). Dengan kata lain, subjek kelompok kontrol secara spontan menetapkan tujuan hasil yang ingin dicapai sebagai manifestasi dari pemenuhan kebutuhan berprestasi, baik pada aspek keterampilan gerak maupun aspek motivasional.

\section{PENUTUP}

Sesuai dengan hasil analisis dan pembahasan dikemukakan beberapa simpulan sebagai berikut. (1) Penetapan tujuan dan pemantauan diri memberikan pengaruh signifikan terhadap hasil belajar keterampilan gerak melempar anak panah dan motivasi intrinsik, baik secara bersama-sama maupun sendirisendiri dan tinggi rendahnya hasil be- 
lajar keterampilan gerak dan motivasi intrinsik yang dimaksud ditentukan oleh interaksi antara penetapan tujuan dan pemantauan diri. (2) Pembelajaran yang berorientasi pada penetapan tujuan dinamik memberikan hasil belajar keterampilan gerak dan motivasi intrinsik yang paling tinggi, diikuti oleh penetapan tujuan proses, dan paling rendah dicapai oleh penetapan tujuan hasil. (3) Pembelajaran yang dilengkapi dengan pemantauan diri menunjukkan hasil belajar lebih tinggi dan signifikan daripada pembelajaran yang tidakmenggunakan pemantauan diri baik pada variabel keterampilan gerak melempar anak panah maupun motivasi intrinsik. (4) Dilihat dari interaksi antar faktor dengan setiap klasifikasi disimpulkan bahwa efektifitas pembelajaran yang dilengkapi dengan pemantauan diri dipengaruhi oleh penetapan tujuan dan sebaliknya efektivitas hasil belajar yang berorientasi pada penetapan tujuan dipengaruhi pula oleh pemantauan diri.

Hal ini berarti, ada pengaruh interaksi antara penetapan tujuan dengan pemantauan diri terhadap hasil belajar keterampilan gerak melempar anak panah dan motivasi intrinsik pada anak usia Sekolah Dasar. Ketika dibandingkan dengan kelompok kontrol, hasil belajar keterampilan gerak melempar anak dan motivasi intrinsik semua kelompok eksperimen lebih tinggi dan signifikan daripada hasil belajar kelompok kontrol kecuali kelompok eksperimen tujuan hasil baik yang dilengkapi dengan pemantauan diri maupun tidak dilengkapi dengan pemantauan diri.

\section{UCAPAN TERIMA KASIH}

Ucapan terima masih disampaikan kepada berbagai pihak yang telah berkontribusi terhadap penelitian yang dilakukan, khususnya pihak sponsor yang telah mendanai penelitian ini. Selain itu, ucapan terima kasih juga disampaikan kepada sejawat yang telah membantu dan seluruh subjek penelitian yang tidak dapat disebutkan satu per satu atas berbagai masukan dan sumbang sarannya. Semoga semua itu menjadi amal ibadah yang diterima Allah SWT. Amin.

\section{DAFTAR PUSTAKA}

Agran, M., Sinclair, T., Alper, S., Cavin, M., Wehmeyer, M., \& Hughes, C. 2005. "Using Self-Monitoring to Increase FollowingDirection Skills of Students with Moderate to Severe Disabilities in General Education". Education and Training in Developmental Disabilities, 40(1), 3-13.

Burton, D. \& Weiss, C. 2008. "The Fundamental Goal Concept: The Path to Process and Performance Success. In Horn, T.S". Advances in Sport Psychology. (hh. 339-376). Ohio: Human Kinetics.

Cox, R. H. 2007. Sport Psychology: Concept and Psychology. Iowa: Wm.C. Brown Publishers.

Elliot, A. J; McGregor, H. A \& Gable, S. 1999. "Achievement Goal, Study Strategy, and Exam Performance: A Mediational Analy- 
sis". Journal of Educational Psychology, 91 (3), 549-563.

Ernsbarger, S.C. 2002. "Simple, Affordable, and Effective Strategies for Prompting Reading Behavior". Reading $\mathcal{E}$ Writing Quarterly, $18,279-284$.

Field, A. 2009. Discovering Statistic Using SPSSS for Windows. London: Safe Publications.

Filby, W.C.D., Maynard, I.W., \& Graydon, J.K. 1999. "The effect of Multiple-Goal Strategies on Perfomrnace Outcomes in Training and Competition". Journal of Applied Sport Psychology, 11 (2), 230-246.

Ghozali, I. 2009. Aplikasi Analisis Multivariate dengan Program SPSS. Semarang: Badan Penerbit Universitas Dipenogoro.

Gould, D. 2001. "Goal Setting for Peak Performance". In Williams, J.M. Applied Sport Psychology. Personal Growth to Peak Performance. (hh.158-169) London: Mayfield Publishing Company.

Jacobson, R. 1998. “Teachers Improving Learning Using Metacognition with Self-Monitoring Learning Strategies". Education, 118, 579-589.

Kerlinger, F.N. 2002. Asas-asas Penelitian Behavioral. Diterjemahkan Si- matupang, L.R. Yogyakarta: Gadjah Mada University Press.

Knudson, D. and Morrison, C. 1996. "An Integrated Qualitative Analysis of Overarm Throwing". The Journal of Physical Education, Recreation and Dance, 7 (6), 31-36.

Moran, A. P. 2004. Sport and exercise Psychology: A Critical Introduction. London: Routledge. Taylor \& Francis Group.

Magill, R. A. 2003. Motor Learning, Concept $\mathcal{E}$ Application. Dubuque: WM. C. Brown Publisher.

Martens, M. P \& Webber, S. N. 2002. "Psychometric Properties of The Sport Motivation Scale: An Evaluation with College Varsity Athletes from The U.S." Journal of Sport and Exercise Psychology, 24, 254-270.

Pelletier, L. G; Fortier, M. S; Vallerand, R. J; Tuson, K. M; Brie`re, N. M \& Blais, M. R. 1995. “Toward a New Measure oF Intrinsic Motivation, Extrinsic Motivation, and Amotivation in Sports: The Sport Motivation Scale (SMS)". Journal of Sport and Exercise Psychology, 17, 35-53.

Sarrazin, P. \& Famose, J. P. 1999. "Children's Goals and Motivation in Physical Education". dalam Auweele, Y. V; Bakker, F; Biddle, S; Durand, $M$ \& Seiler. 
Psychology for Physical Educations. Canada: Human Kinetics.

Schmidt, R. A \&Wrisberg, C. A. 2000. Motor Learning and Performance. Canada: Human Kinetics.

Schunk, D. H. 1985. "Participation in Goal-Setting: Effects on SelfEfficacy and Skills of Learning Disabled Children". Journal of Special Education, 19, 307-317.

Schunk, D. H. \& Ertmer, P. A. 1999. "Self Regulatory Process During Computer Skill Acquisition, Goal, and Self-evaluative Influences". Journal of Educational Psychology, 91 (2) 251-260.

Sarrazin, P. \& Famose, J. P. 1999. "Children's Goals and Motivation in Physical Education". In Auweele, Y. V; Bakker, F; Biddle, S; Durand, M \& Seiler. Psychology for Physical Educations. Canada: Human Kinetics.

Shadish, W. R; Cook, T. D \& Campbell, D. T. 2002. Experimental and Quasi-Experimental Designs for Generalized Causal Inference. Now York: Houghton Mifflin Company.

Silvestri, L. 2001. The Use of "Knowledge of Results in The Acquisition and Performance of Motor Skills". Education, 109 (2), 178-183.
Smith, D. E. 2001. "Psychological Skills Training For Secondary School Sports In Singapore". Journal of ICHPER ${ }^{*}$ D , 36 (2) , 54-57.

Steinberg, G. M. \& Maurer, M. 1999. "Theoretical Implications and Practical Approaches for Motor Skill Instruction". Journal of Physical Education, Recreation, $\mathcal{E}$ Dance, 70 (2), 61-65.

Tan, S. 1997. "The Elements of Expertise". Journal of Physical Education, Recreation and Dance, 68 (2), 30-33.

Widarjono, A., 2010. Analisis Statistik Multivariat Terapan. Yogyakarta: UPP STIM YKPN.

Zimmerman, B. J and Kitsantas, A. 1996. "Self-Regulated Learning of a Motoric Skill: The Role of Goal Setting and Self-Monitoring". Journal of Applied Sport Psychology, (8), 60-75.

. 1997. “Developmental Phases in Self-Reglation: Shifting From Process to Outcome Goals". Journal of Educational Psychology, 89 (1), 29-36.

. 1999. "Acquiring Writing Revision Skill: Shifting From Process to Outcome Self Regulation Goal". Journal of Educational Psychology, 91 (2), 241-254. 